\title{
SYMPTOMS, SIDE-EFFECTS AND SENILITY [OR, THE HEALTH PROFESSIONAL AS A CAUSE OF DEPENDENCY IN OLD AGE]
}

\author{
..." second childishness and mere oblivion, \\ sans teeth, sans eyes, sans taste, sans everything" .... \\ G. S. WATERMEYER, M.B., Ch.B., F.C.P. (S.A.)*
}

\begin{abstract}
SUMMARY
Many elderly people develop a multiplicity of physical and psuchological problems in association with advancing age. II has become possible for the health professions 10 do a great deal to limit the extent of disability and improve the sumptomalology, thus improving quality of life. Massive advances have laken place in the field of pharmacology and therapeutics. Many of the medicines utilised have unloward side-effects in the elderly; side-effects which are frequently not recognised timeously. A ferr of the side-effects are discussed in some detail and pleas are made for the judicious application of lherapeutic schedules to problems in the elderly, recognising the dangers inherent in multiple prescribing.
\end{abstract}

\section{OPSOMMING}

Baie bejaardes onmikkel veelvoudige fisiese en psigiese probleme verwant aan gevorderde jare. Dit het vir lede van gesondheidsberoepe moontlik geword om baie te doen om dic omvang van gestremalheid te beperk en om simptomatologie, en dus lewenskwalieit, te verbeter. Groot vordering het plaasgevind in farniakologie en terapic. Baie geneesmiddels het ongunstige newe-effekte in bejaardes; newe-effekte wat dikwels nie betyds herken word nie. 'n Paar van die neweeffekle word in detail bespreek en 'n pleidooi gemaak vir oordeelkundige aanwending van terapeuticse skedules vir problene van bejaardes, met herkenning van die gevaar van veelvoudige voorskrying.
With the industrialised Western society reaching the pinnacle of its development and influence, it has become possible for an increasing proportion of the population to achieve and exceed the biblical allocation of threescorc vears and ten. Many industrialised countries are approaching a situation where one in every five of its citizens can be classified as elderly.

A well-recognised sight in most towns in South Africa has become the elderly pensioner happily pursuing his interests, meeting up with his friends and peers with enough time to do the things that he has always wanted to do.

The health care professions find that an increasing proportion of their work-load is concerned with the care of elderly people. Nurses, physiotherapists, occupational therapists and social workers are able to do a great deal to maintain the elderly as active, independent members of the community.

Similarly, doctors and pharmacists fulfil a vastly important role in the maintenance of health of the elderly person. They are in a position to materially affect the outcome of many of the disabling and life-threatening diseases to which elderly people show an increased susceptibility.

In earlier times some of the main diseases which afflicted the elderly included congestive cardiac failure, angina pectoris, obstructive lung disease and a variety of psychological and neurological syndromes ranging from depression to Parkinson's disease.

In addition to these clearly defined entities, there are a few physiological phenomena which appear to be altered in the clderly. These include a tendency to sleep less, to have fewer

* Professor and Head of Department of Community Health, University of Cape Town.

Received 7 June 1982. bowel actions and to be generally physically slower than their more youthful counterparts.

These alterations in function go hand-in-hand with marked changes in metabolic function in a varicty of organ systems. For example, the creatinine clearance falls, the digestive system operates less efficiently, leading to a tendency to malabsorption of essential nutricnts, and the erythrocyte sedimentation rate rises, to namc but a few.

\section{CLINICAL TIHERAPEUTIC IMPLICATIONS}

Improved diagnostic and therapcutic skills and facilities result in better control of most of the common afflictions of the elderly. Modern advances in pharmacology and therapeutics permit the achievement of a marked degrce of symptomatic relief for most of the otherwise disabling chronic diseases of advancing age. Somc problems do emerge however.

\section{Altered Dose-response}

With the advent of modern therapies for, for example: congestive cardiac failure and ischaemic heart discasc. crippling dyspnoea, swelling and angina pectoris are totally relieved, resulting in a vast improvement in quality of life. What is frequently not appreciated, however, is the fact that all these modern medicines are associated with the development of significant disabling side-effects, especially in the elderly. The patient with ischaemic heart discase may receive Propranolol for his angina pectoris, which improves that symptom, but results in severe bronchospasm and cardiac failure, not to mention serious depression and a degree of mental confusion. In a younger person with. a similar problem the same dose of drug would present no sideeffects, but, because of altered pharmacokinetics in the elderly, this drug becomes problematical at an otherwise normal dose. 


\section{Untoward Effects}

Another phenomenon frequently encountered in an elderly patient relates to the manifestation of unusual symptoms relating to the drug. Digitalis preparations used in nornal dosage in the elderly are not infrequently associated with mental change, leading to the development of depression, confusion, manic behaviour and the diagnosis of senility. Sedatives and hypnotics, like diazepam, may result in confusion, loss of memory and, again, a diagnosis of senile dementia.

\section{Polypharmacy}

The natural history of advancing age represents a progressive reduction in function of all organ-systems. It is therefore logical that many elderly people will present with a multiplicity of complaints and have more than one clinical diagnosis. It is common, e.g. for diabetes mellitus to co-exist in the elderly with an infection, ischaemic heart disease, a degree of renal decompensation and peripheral neuritis. Each modality produces symptoms and requires treatment in its own right. Research has shown that the risk of side effects rises exponentially when multiple prescriptions are utilized in younger individuals (Bourne, Heddon and Watermeyer, 1979). In the elderly this risk is even greater.

In a study carried out in a psychogeriatric unit (Watermeyer, 1979) it was shown that in fully one-third of elderly people admitted with a mixture of psychiatric and physical health problems, the precipitating factor responsible for the admission related to side-effects from one or more drugs utilized, often for doubtful indications. Drug withdrawal under supervision and the restitution of fluid and electrolyte balance resulted in symptomatic improvement in 68 percent of patients.

\section{WHAT DOES IT ALL MEAN?}

As a health professional, one is regularly reminded of the importance of viewing disease as a disturbance, not just of physical function, but also as a disruption of psychological and social planes of existence. It appears nowadays that we may indeed cause physical. psychological and social dysfunction by our very attempts to alleviate the symptoms which have brought a patient to us in the first place. It behoves us therefore to remember another ancient dictum when we deal with septuagenarians, octogenarians and suchlike - namely primum non nocere - if we can't do any good, let us at least do no harm.

Modern medical science permits us to do both harm and good for those under our care. It behoves all of us to consider side-effects as well as benefits of treatment schedules to achieve maximum improvement in quality of life.

\section{References:}

Bourne, D., Heddon, D. and Watermeyer, G. S. (1979). A theoretical technique for examining the probability of interactions in multiple prescriptions. South Afr I Science, 75,320 .

Watermeyer, G. S. (1979). Some causes of disability in the elderly of Cape Town. $S A$ Med.J. 56, 416. 